\title{
Distribution of Multi-Resistant Bacterial Isolates from Clinical Specimens in a Hospital Environment of Kingdom of Saudi Arabia
}

\author{
Sirajudeen S. Alavudeen *, Easwaran Vigneshwaran, Sultana Ali Abdullah Asiri, Manal Hamood Awad Alahmari, \\ Maha Abdullah Mohammed, Thikra Algahtani, Noohu Abdullah Khan \\ Department of Clinical Pharmacy, King Khalid University, Abha, Kingdom of Saudi Arabia.
}

\begin{abstract}
Objective: The problem of antimicrobial resistance in Kingdom of Saudi Arabia is an emerging problem where the complete elimination of antimicrobial resistance is impossible due to the irrational use of antibiotics worldwide and in Saudi Arabia. Thus, the present study was undertaken to determine the prevalence of bacterial pathogens and to assess the multidrug resistant (MDR) strains to different antibiotics in Aseer Region, Kingdom of Saudi Arabia. Method: A retrospective analysis of 163 subjects diagnosed with variable infections during the period of February - May 2015. The study was conducted at a 500 bedded tertiary health care center. The data were collected from microbiological laboratory and patient case sheet. The bacterial isolates are categorized as sensitive or resistant based on the zone of inhibition of antibiotics. Results: Total of 15 different strains of gram positive and negative were isolated where, a urine specimen was found to have the highest number of bacterial isolates $(28.8 \%)$ and intensive care unit (ICU) had more number of isolates. Among 46 antibiotics tested, only 12 antibiotics were included in the analysis. Almost, most of the gram positive and gram negative bacterial isolates had resistance to more than three antimicrobials, which satisfies the criteria to call them
\end{abstract}

as multidrug resistant bacterial isolates. Conclusion: Overall prevalence of antibiotic resistance to the commonly used antibiotics was high in the bacterial isolates selected in our study center, which warrants the infection control to reduce resistance.

Key words: Resistance, Prevalence, Antimicrobials, Bacterial isolates, Saudi Arabia.

Key message: specific antibiotic guidelines needs to be prepared for the study center and the region since the prevalence of antibiotic resistance is high.

Correspondence :

Sirajudeen S Alavudeen, Department of clinical pharmacy, King Khalid University, Abha, Kingdom of Saudi Arabia.

Phone: +966507583500

Email: asiraj2005@gmail.com

DOI: 10.5530/jyp.2017.9.69

\section{INTRODUCTION}

The control of bacterial infections is challenging task for health care professionals because of the emergence of bacterial resistance. Antimicrobial resistance is a major threat to health care industry worldwide. Resistance may compromise treatment, leading to increased mortality, extended hospital stays and greater healthcare costs. ${ }^{1,2}$ The involvement of primary healthcare is particularly important as this is where almost $80 \%$ of all antibiotics used within the health service are prescribed. ${ }^{3}$ The antibiotic resistance level may occur in any environment and it may be further stimulated with irrational antimicrobial use. ${ }^{4,5}$

Antibiotics are evolving as environmental pollutants, causing both shortterm and long-term changes in microorganisms with their enormous biological activities. Bacterial resistance to antibiotics has been considered as a global public health menace, and keep on increasing. Different kinds of antibiotic resistant bacteria (ARB) are continuously detected in various environments. ${ }^{6,7}$ In addition to that, there are wide variety of factors play a role in emergence of resistance. Those factors include inappropriate use of antibiotics, transmission of resistant bacteria through various resources in the health care system, lack of proper guidelines for antimicrobial use etc. There are few reports have described the prevalence of antimicrobial resistance in Kingdom of Saudi Arabia..$^{1-8}$ The problem of antimicrobial resistance in Kingdom of Saudi Arabia is an emerging problem where, the complete elimination of antimicrobial use is not possible due to persistent existence of infectious diseases worldwide and in Saudi Arabia. ${ }^{9}$ Therefore, it requires some other alternative. The suggested alternative solution may be the development of antibiotic usage guidelines and policies to restrict the use of antimicrobials. Unfortunately, most of the countries in GCC (Gulf corporation council) lacks with guidelines for the usage of antimicrobials and policy to restrict the use of antimicrobials including Kingdom of Saudi Arabia. ${ }^{10,11}$ Thus, it is expected that the possibility of antimicrobial resistance may be high. The available data from various regions of Kingdom of Saudi Arabia gives a clear idea of existence of antimicrobial resistance, whereas the reports of antimicrobial resistance from the Aseer region of the Kingdom of Saudi Arabia are scarce. A better knowledge on the emergence of antimicrobial resistance may be useful to develop and frame the antimicrobial guidelines and usage policies. Thus, the present study was designed as a preliminary study to develop the antibiotic usage guidelines and to frame antibiotic usage policies to restrict the usage of antibiotics in near future. Therefore, the present study was undertaken to determine the prevalence of bacterial pathogens and to assess the multi-drug resistant (MDR) strains to different antibiotics in Aseer Region, Kingdom of Saudi Saudi Arabia.

\section{METHOD}

A retrospective analysis included all patients diagnosed with variable infections such as respiratory infections, urinary tract infections, blood 
stream Septicaemia, skin and soft tissue infections and etc. during the period of February 2015 to May 2015.

The study was conducted at Aseer central hospital located at Aseer region of Kingdom of Saudi Arabia in different specialty wards including ICU, CCU \& IMCU. Aseer Central Hospital (ACH) (Abha, Saudi Arabia) is a tertiary health care center with over 500 beds. It is the referral center for the Aseer region of Southern Saudi Arabia.

Demographic and other clinical data includes patient age, sex, site of infection, date of specimen collection, previous history of antibiotics usage for the past two days before the collection of specimen, diagnosis, ward and specialty were collected from the available database at microbiological laboratory and patient case sheet. It included only the inpatients those who are having positive culture reports during the study period.

The bacterial isolates were identified and obtained from various specimens of blood, urine, sputum, bronchoalveolar lavage/tracheal secretions and other sites. The specimens cultured on an agar medium. The growths of colonies were identified based on culture, biochemical and microbiological method as per standard protocols. ${ }^{12}$

The antimicrobial testing was performed by the disk diffusion method using Muller-Hinton agar plates as per the National Committee for Clinical Laboratory standards. ${ }^{8}$ Only isolates derived from patients at the present study center were considered in the analysis. The recommended Standard antibiotics disks (Oxoid) were used, which were placed on to agar medium with single disk applicator. Then the plates were incubated to observe growth colonies and to estimate zone of inhibition. The bacterial isolates were then categorized as sensitive or resistant based on zone of inhibition.

Total of 46 antibiotics were tested for antimicrobial susceptibility among the bacterial isolates in this study. But only 12 antibiotics were included in the analysis for the evaluation of antimicrobial resistance, because of their frequent usage in the present study site. Descriptive statistics were done for the analysis of data by using Microsoft office excel version 2016.

\section{RESULTS}

A total of 163 subjects were included in the present study. Both the genders were included in this study (male - $80.4 \%$ and female - 19.6\%), with varied age. The mean age of the study subjects was found to be $50.25 \pm 24.14$. (Range from 16 years to 19 years). Among the various specimens tested, urine specimen was found to have the highest number of bacterial isolates $(28.8 \%)$. The sputum and blood culture shows $23.9 \%$ and $15.3 \%$ of bacterial isolates respectively. The remainder were derived from various sources of specimen such as wound, tracheal secretions, throat swab and etc. More than $60 \%$ of all organisms were from the patients those who were admitted in intensive care unit (ICU). The $22.7 \%$ of isolates were from the patients' undergone treatment in intermediate care unit (IMCU). Just the $10 \%$ is from all other departments. (Table 1.) About the prevalence of bacteria in our study, $85.88 \%$ of the patients $(\mathrm{n}=140)$ harbored with gram negative bacteria and the remaining (14.11\%) were harbored with gram positive bacteria. Around 15 different strains of gram positive bacteria and 7 different strains of gram negative bacteria were isolated from the study subjects.

The most common gram-positive isolates were Staphylococcus aureus (3.06\%), Staphylococcus haemolyticus (3.06\%), Staphylococcus captis (2.45\%). The rest of the gram-positive strains were comparatively rare. Escherichia coli (16.6\%), Proteous mirabilis (11.7\%), Klebsiella pneumonia (9\%), Morganella morganii (6\%) were the most common enterobacteriaceae. However, the highest number of isolates found in gram negative bacteria is Acinetobacter baumannii (21.47\%). The other gram negative isolates identified in this study are very rare. The details are depicted in Table 2.
Table 1: Prevalence of bacterial isolates based on specimen and Specialty/Wards

\begin{tabular}{cccc}
\hline Specimen & N (\%) & Specialty /Wards & N (\%) \\
\hline Urine & $41(25.2)$ & IMCU & $110(67.5)$ \\
Sputum & $33(20.2)$ & ICU & $37(22.7)$ \\
Blood & $22(13.5)$ & MSW & $6(3.7)$ \\
Endotracheal tube & $18(11.1)$ & MGS & $2(1.2)$ \\
Wound & $16(9.8)$ & Urology & $2(1.2)$ \\
Tracheal secretion & $15(9.2)$ & CCU & $1(0.6)$ \\
Throat swab & $8(4.9)$ & MMW & $1(0.6)$ \\
Abscess & $3(1.8)$ & FS & $1(0.6)$ \\
Bedsore swab & $2(1.2)$ & Emergency & $1(0.6)$ \\
Nasal swab & $2(1.2)$ & IMR & $1(0.6)$ \\
Rectal swab & $1(0.6)$ & GS & $1(0.6)$ \\
Skin swab & $1(0.6)$ & & \\
Stool & $1(0.6)$ & & \\
\hline
\end{tabular}

\section{Table 2: The frequency of microorganisms isolated from patients}

\begin{tabular}{|c|c|c|c|}
\hline $\begin{array}{c}\text { Gram } \\
\text { negative organisms }\end{array}$ & $\mathrm{N}(\%)$ & $\begin{array}{l}\text { Gram positive } \\
\text { organisms }\end{array}$ & N (\%) \\
\hline Acinetobacter baumannii & $35(21.47)$ & Proteous mirabilis & $19(11.66)$ \\
\hline Escherichia coli & $27(16.56)$ & $\begin{array}{c}\text { Staphylococcus } \\
\text { aureus }\end{array}$ & $5(3.06)$ \\
\hline Klebsiella pneumonia & $15(9.20)$ & $\begin{array}{l}\text { Staphylococcus } \\
\text { haemolyticus }\end{array}$ & $5(1.22)$ \\
\hline Pseudomonus aeruginosa & $11(6.75)$ & $\begin{array}{l}\text { Staphylococcus } \\
\text { captis }\end{array}$ & $4(2.45)$ \\
\hline Morganella morganii & $10(6.13)$ & $\begin{array}{l}\text { Staphylococcus } \\
\text { epidermidis }\end{array}$ & $3(1.84)$ \\
\hline Providencia stuartii & $7(4.29)$ & $\begin{array}{c}\text { Staphylococcus } \\
\text { hominis subsp. } \\
\text { hominis }\end{array}$ & $2(1.84)$ \\
\hline Enterobacter aerogenes & $4(2.45)$ & $\begin{array}{l}\text { Enterococcus } \\
\text { faecium }\end{array}$ & $2(1.22)$ \\
\hline Serratia marcescens & $3(1.84)$ & $\begin{array}{c}\text { Staphylococcus } \\
\text { auricularis }\end{array}$ & $1(0.61)$ \\
\hline Enterobacter cloacae & $3(1.84)$ & $M R S A$ & $1(0.61)$ \\
\hline Citrobacter koseri & $2(1.22)$ & & \\
\hline $\begin{array}{l}\text { Stenotrophomonas } \\
\text { maltophilia }\end{array}$ & $1(0.61)$ & & \\
\hline Salmonella species & $1(0.61)$ & & \\
\hline Klebsiella oxytoca & $1(0.61)$ & & \\
\hline Pseudomonas stutzeri & $1(0.61)$ & & \\
\hline
\end{tabular}

The frequency of antimicrobial susceptibility and resistance of gram positive isolates are indicated in Table 3. Fluoroquinolones were found to have a very good efficacy on S.aureus. Resistance pattern of the S. aureus was little bit low. Staph haemolyticus was found to have a resistance to more than five antimicrobials, at the same it was susceptible to only gentamycin and co-trimoxazole. We could not able to identify even a single gram positive bacterial isolate without resistance pattern to the tested antibiotics. Instead figured out the multiple drug resistance pattern to all the gram-positive bacteria isolated and evaluated in this study. 

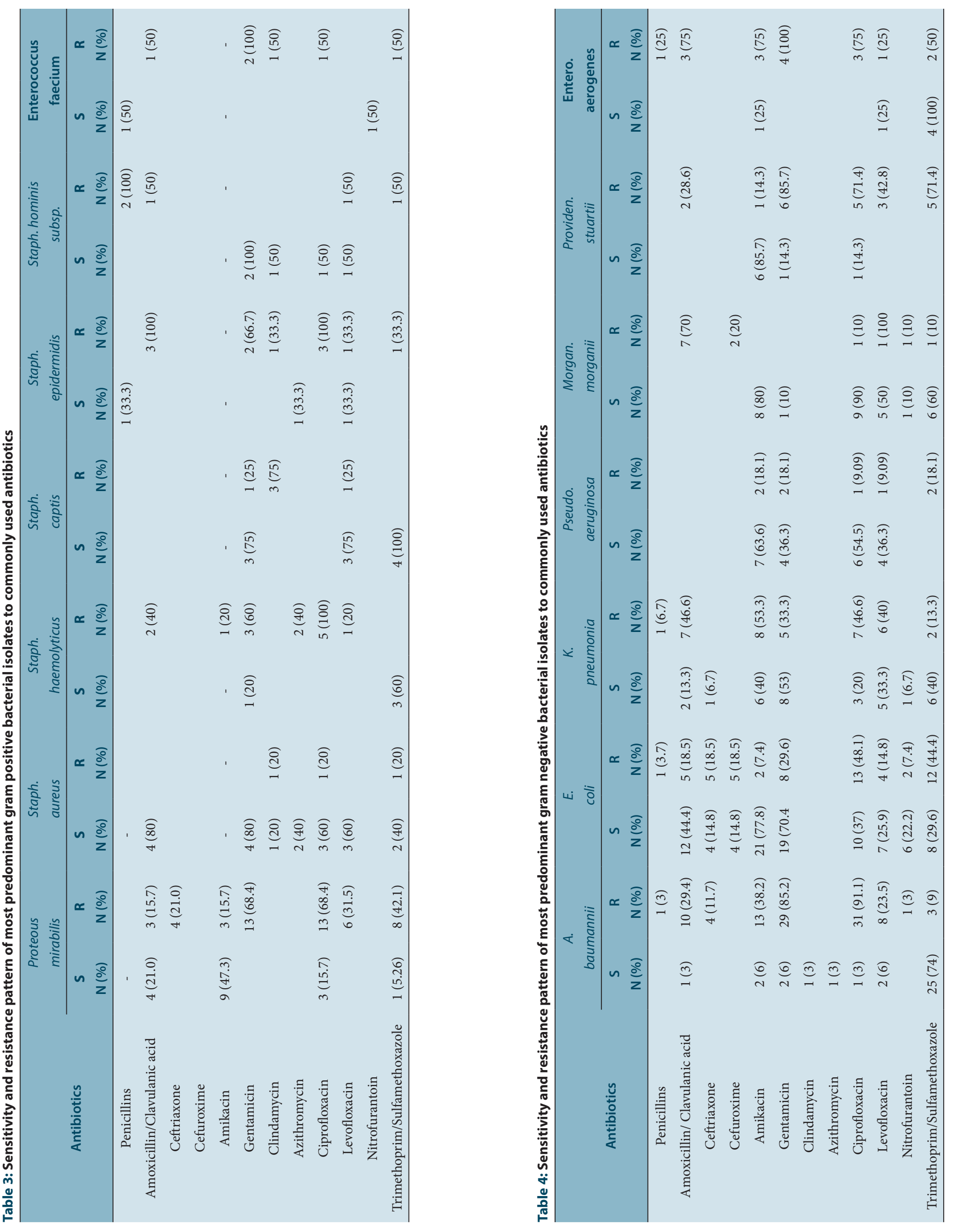
Table 5: List of multidrug resistant strains to commonly used antibiotics
Gram positive strains

Staph. aureus

Staph. haemolyticus

Staph. captis

Staph. epidermidis

Staph. hominis subsp.

Enterococcus faecium
Gram negative strains

A. baumannii

E. coli

K. pneumonia

Pseudo. aeruginosa

Morgan. morganii

Providen. stuartii

Entero. aerogenes
The frequency of antimicrobial susceptibility and resistance of gram negative isolates are indicated in Table 4. Clindamycin and azithromycin were found to have efficacy only against A.baumannii, that too on only one isolate among gram negative isolates. Further, these two agents showed no sensitivity or resistance against any other gram negative isolates. A.baumannii, E.coli, Proteus mirabilis, and K. pneumonia were found to have resistance to more than or equal to seven antimicrobial agents. But still, these strains show sensitivity to these agents. We failed to recognize even a single gram negative bacterial isolate without resistance pattern to tested antibiotics. Further, we identified aminoglysocides and fluroquinolones showed a very good sensitivity to all the gram-negative isolates, except Proteus mirabilis. Amoxicillin and clavulanic acid combination shows a good sensitivity against all gram-negative isolates except, Pseudomonas aeruginosa, and Morgan morganii. Trimethoprim and Sulfamethoxazole combination shows a good sensitivity against all gram-negative isolates except, Pseudo. Aeruginosa, and Providen stuartii. Almost, most of the gram positive and gram negative bacterial isolates had resistance pattern to more than three antimicrobials, which satisfies the criteria to call them as multidrug resistant bacterial isolates (Table 5).

\section{DISCUSSION}

The severity and extent of disease caused by multi resistant bacterial pathogens varies by the population(s) affected and by the institution(s) in which they are found, but the prevention and control of these multi resistant bacterial pathogens should be a national priority. ${ }^{13}$ The antibiotic sensitivity pattern of organisms is keep on changing very rapidly, particularly in countries like Saudi Arabia and is observed worldwide as well. ${ }^{8-14}$ Hence periodic evaluation of antimicrobial use and resistance is essential. In this study the highest prevalence of bacteria was isolated from urine followed by sputum, blood and wound infections. More or less a similar result was reported by MS Shahidullah et al. ${ }^{15}$

Negative outcome of inadequate and inappropriate antimicrobial treatment of infections caused by antibiotic-resistant bacteria has been shown in previously published studies. ${ }^{16-19}$ Hence it is suggested that the physicians need to re-evaluate initial therapies to ensure appropriate antibiotic coverage. As suggested, all ICUs in hospitals need to have locally improved and frequently revised guidelines for the use of antibiotics. Since this may have an effect on local resistance patterns. ${ }^{20}$ In the present study, we have seen an extensive resistance patterns among bacterial isolates and most of them were obtained from ICU. Thus, it requires quality control of antibiotic usage and locally prepared guidelines not only at the ICU level even at the hospital level.

We have clearly demonstrated that the degree of contamination with multi-resistant Gram-positive and Gram-negative pathogens more or less equal. These results are in contrast with the study published by Lemmen SW et al. in 2003, where they demonstrated the contamination of multi resistant gram positive pathogens were higher than multi resistant gram negative pathogens. ${ }^{21}$
The organisms associated with the infections were Staphylococcus aureus, Proteus mirabilis, Pseudomonas aeruginosa, Klebsiella pneumoniae, Escherichia coli and Enterobacter Spp. These findings agree with those reported by Anguzu et al. ${ }^{22}$ In the present study, the isolates were derived from variety of clinical specimens, whereas, Anguzu et al. derived the isolates from wound infections.

The majority of gram positive bacterial isolates were found to have resistance to cephalosporins in our study, whereas, this is in contrast with other study published by Sheth et al. that they were resistant to macrolide antibiotics. $^{23}$

Most gram-negative bacteria isolated were sensitive to gentamicin and ciprofloxacin. However, most of the gram-negative bacteria isolated were resistant to macrolides. These results were similar to the study reported by Seppala et al. ${ }^{24}$ The resistance shown to macrolides might be due to frequent and large administration. In addition, they were used in prophylaxis treatment. This kind of over usage may lead to antibiotic resistance.

A multi-hospital study on antimicrobial usage and resistance has reported that the microbiology department must have close relationship with pharmacy and infection control committee to ensure appropriate use of antibiotics. They also reported that multi-hospital study may not identify the relationship between antimicrobial usage and antimicrobial resistance. ${ }^{25}$ But it is already proven concept that the antibiotic usage have concrete relationship with antimicrobial resistance. ${ }^{26-28}$

Even though we did not evaluate the correlation between antibiotic usage and resistance, the present study results show that there is possibility for the isolates to have multiple drug resistance. It encourages us to explore the present study more to evaluate the correlation between antimicrobial usage and resistance. It will be more useful in developing guidelines and antibiotic policies for the appropriate use of antibiotics.

Several studies have described the positive effect on resistance through restricted antibiotic use in ICU and other departments of the hospital. ${ }^{29-30}$ Moreover, Burke et al. have explained that a computer-assisted decision support program for prescribing antibiotics have an important role in controlling bacterial resistance in the ICU. ${ }^{29}$

\section{CONCLUSION}

Our findings indicate that the overall prevalence of antibiotic resistance to the commonly used antibiotics was high in the bacterial isolates selected in our study center, which warrants the infection control to reduce resistance. This calls for attention of health professionals and policy makers to consider the resistance pattern in their clinical practice, and policy making process respectively.

Most importantly, these data may be used to control trends of antibiotic susceptibilities, to develop local antibiotic policies and to assist clinicians in the rational choice of antibiotic therapy. Thus, it may be useful to decrease the inappropriate use of antibiotics. However, future studies should be extended to include specific cultures to develop individual guidelines.

\section{ACKNOWLEDGEMENT}

The authors would like to express their gratitude to The Dean and Vice dean of College of Pharmacy, King Khalid University, Abha, Kingdom of Saudi Arabia.

\section{CONFLICT OF INTEREST}

The authors declare having no conflict of interest. 


\section{ABBREVIATION USED}

ACH: Aseer Central Hospital; ARB: Antibiotic Resistant Bacteria; CCU: Cardiac Care Unit; GCC: Gulf Corporation Council; ICU: Intensive Care Unit; IMCU: Intermediate Care Unit; MDR: Multi Drug Resistant.

\section{REFERENCES}

1. Yezli S, Shibl AM, Livermore DM, Memish ZA. Prevalence and antimicrobial resistance among Gram-negative pathogens in Saudi Arabia. J Chemother Florence Italy. 2014;26(5):257-72. https://doi.org/10.1179/1973947814Y.0000000185; PMid:24669827.

2. Topno I, Chennama B, Yugandhar B, Balakrishnan S. Antibiotic prescribing pattern in ophthalmology outpatient department in a tertiary care hospital. J Pharmacol Pharmacother. 2012;3(2):190-1. PMid:22629098 PMCid:PMC3356964.

3. Bryce A, Hay AD, Lane IF, Thornton HV, Wootton M, Costelloe C. Global prevalence of antibiotic resistance in paediatric urinary tract infections caused by Escherichia coli and association with routine use of antibiotics in primary care: systematic review and meta-analysis. BMJ. 2016;15;352:1939.

4. Bin BY, Rozina A, Junaid M, Saima K, Farhan N, Maham T. A Study of Unnecessary Use of Antibiotics at a Tertiary care hospital: Urgent need to implement antimicrobial stewardship programs. J Young Pharm. 2015:17:7(4):311-9.

5. Al Akhali KM, Alzomar AK, Khan NA, Alavudeen SS. Misuse of antibiotics and awareness of antibiotic hazard among the public and medical professionals in Thamar province, in republic of Yemen. Pharm Glob Int J Compr Pharm. 2013;1(4):1-4

6. Goswami NN, Trivedi HR, Goswami APP, Patel TK, Tripathi CB. Antibiotic sensitivity profile of bacterial pathogens in postoperative wound infections at a tertiary care hospital in Gujarat, India. J Pharmacol Pharmacother. 2011;1;2(3):158.

7. Hoque R, Mostafa A, Haque M. Insight of Medical Students of Clinical Years to Antimicrobials Prescribing and Resistance in Private Medical School, Chittagong, Bangladesh. J Young Pharm. 2016;1;8(4):447-55.

8. Hamid ME, Mustafa FY, Alwaily A, Abdelrahman S, Al Azragi T. Prevalence of Bacterial Pathogens in Aseer Region, Kingdom of Saudi Arabia: Emphasis on Antimicrobial Susceptibility of Staphylococcus aureus. Oman Med J. 2011;26(5):368-70. https://doi.org/10.5001/omj.2011.91; PMid:22216389 PMCid:PMC3230239.

9. Mah MW, Memish ZA. Antibiotic resistance. An impending crisis. Saudi Med J. 2000;21(12):1125-1129. PMid:11360084

10. Aly $\mathrm{M}$, Balkhy $\mathrm{HH}$. The prevalence of antimicrobial resistance in clinical isolates from Gulf Corporation Council countries. Antimicrob Resist Infect Control. 2012;1(1):26. https://doi.org/10.1186/2047-2994-1-26; PMid: 22958584 PMCid: PMC3436690.

11. Memish ZA, Ahmed QA, ArabiYM, Shibl AM, Niederman MS, GCC CAPWorking Group. Microbiology of community-acquired pneumonia in the Gulf Corporation Council states. J Chemother Florence Italy. 2007;19(Suppl 1):17-23. https://doi.org/10.1080/1120009X.2007.11782430 : https://doi.org/10.1080/11 20009X.2007.11782428 : https://doi.org/10.1080/1120009X.2007.11782431 https://doi.org/10.1080/1120009X.2007.11782432 : https://doi.org/10.1080/1120 009X.2007.11782429; PMid:18073166

12. Hall BG, Acar H, Nandipati A, Barlow M. Growth Rates Made Easy. Mol Biol Evol. 2013;28:187.

13. Al Johani SM, Akhter J, Balkhy H, El-Saed A, Younan M, Memish Z. Prevalence of antimicrobial resistance among gram-negative isolates in an adult intensive care unit at a tertiary care center in Saudi Arabia. Ann Saudi Med 2010;30(5):364-9. https://doi.org/10.4103/0256-4947.67073.

14. Memish ZA, Shibl AM, Kambal AM, Ohaly YA, Ishaq A, Livermore DM. Antimicrobial resistance among non-fermenting Gram-negative bacteria in Saudi Arabia. J Antimicrob Chemother. 2012;67(7):1701-5. https://doi.org/10.1093/jac/ dks091 : PMid:22461312.
15. Shahidullah MS, Yusuf MA, Khatun Z, Ara U, Mitul MT. Antibiotic Sensitivity Pattern of Bacterial Isolates from Different Clinical Specimens: Experience at NICVD, Dhaka. Cardiovasc J. 2012:5(1):67-72. https://doi.org/10.3329/cardio. v5i1.12276.

16. Savage RD, Fowler RA, Rishu AH, Bagshaw SM, Cook D, Dodek $P$, et al. The Effect of Inadequate Initial Empiric Antimicrobial Treatment on Mortality in Critically III Patients with Bloodstream Infections: A Multi-Centre Retrospective Cohort Study. PloS One. 2016;11(5):e0154944. https://doi.org/10.1371/journal. pone.0154944 ; PMid:27152615 PMCid:PMC4859485.

17. Ibrahim EH, Sherman G, Ward S, Fraser VJ, Kollef $\mathrm{MH}$. The influence of inadequate antimicrobial treatment of bloodstream infections on patient outcomes in the ICU setting. Chest. 2000;118(1):146-55. https://doi.org/10.1378/ chest.118.1.146; PMid:10893372.

18. Zaragoza R, Artero A, Camarena JJ, Sancho S, González R, Nogueira JM. The influence of inadequate empirical antimicrobial treatment on patients with bloodstream infections in an intensive care unit. Clin Microbiol Infect. 2003;9(5):412-8. https://doi.org/10.1046/j.1469-0691.2003.00656.x ; PMid:12848754.

19. Marquet K, Liesenborgs A, Bergs J, Vleugels A, Claes N. Incidence and outcome of inappropriate in-hospital empiric antibiotics for severe infection: a systematic review and meta-analysis. Crit Care [Internet]. 2015 [cited 2016 Oct 23];19(1).

20. Hanberger $H$, Diekema $D$, Fluit $A$, Jones $R$, Struelens $M$, Spencer $R$, et al Surveillance of antibiotic resistance in European ICUs. J Hosp Infect. 2001; 48(3):161-76. https://doi.org/10.1053/jhin.2001.0987; PMid:11439002.

21. Lemmen SW, Häfner $H$, Zolldann D, Stanzel S, Lütticken R. Distribution of multi-resistant Gram-negative versus Gram-positive bacteria in the hospita inanimate environment. J Hosp Infect. 2004;56(3):191-7. https://doi.org/10.1016/ j.jhin.2003.12.004 ; PMid:15003666

22. Anguzu J, Olila D. Drug sensitivity patterns of bacterial isolates from septic post-operative wounds in a regional referral hospital in Uganda. Afr Health Sci. 2007;7(3):148-54. PMid:18052868 PMCid:PMC2269712.

23. Sheth K, Patel T, Malek S, Tripathi C. Antibiotic Sensitivity Pattern of Bacterial Isolates from the Intensive Care Unit of a Tertiary Care Hospital in India. Trop J Pharm Res [Internet]. 2013 Feb 25 [cited 2016 Oct 23];11(6).

24. Seppälä H, Nissinen A, Järvinen $H$, Huovinen $S$, Henriksson T, Herva $E$ et al. Resistance to erythromycin in group A streptococci. N Engl J Med. 1992;30;326(5):292-7.

25. Lesch CA, Itokazu GS, Danziger LH, A. Weinstein R. Multi-hospital analysis of antimicrobial usage and resistance trends. Diagn Microbiol Infect Dis. 2001;41(3):149-54. https://doi.org/10.1016/S0732-8893(01)00296-6.

26. Willemsen I, Bogaers-Hofman D, Winters M, Kluytmans J. Correlation between antibiotic use and resistance in a hospital: temporary and ward-specific observations. Infection. 2009;37(5):432-7. https://doi.org/10.1007/s15010-009 8325-y; PMid:19499184

27. Lai C-C, Wang C-Y, Chu C-C, Tan C-K, Lu C-L, Lee Y-C, et al. Correlation between antibiotic consumption and resistance of Gram-negative bacteria causing healthcare-associated infections at a university hospital in Taiwan from 2000 to 2009. J Antimicrob Chemother. 2011;66(6):1374-82. https://doi. org/10.1093/jac/dkr103; PMid:21436153.

28. Velickovic-Radovanovic R, Petrovic J, Kocic B, Antic S, Randelovic G Correlation between antibiotic consumption and bacterial resistance as quality indicator of proper use of these drugs in inpatients. Vojnosanit Pregl. 2009:66(4):307-12. https://doi.org/10.2298/VSP0904307V; PMid:19432297.

29. Burke JP, Pestotnik SL. Antibiotic use and microbial resistance in intensive care units: impact of computer-assisted decision support. J Chemother Florence Italy. 1999;11(6):530-5. https://doi.org/10.1179/joc.1999.11.6.530; PMid:10678796.

30. Gruson D, Hilbert G, Vargas F, Valentino R, Bebear C, Allery A, et al. Rotation and restricted use of antibiotics in a medical intensive care unit. Impact on the incidence of ventilator-associated pneumonia caused by antibiotic-resistant gram-negative bacteria. Am J Respir Crit Care Med. 2000;162(3 Pt 1):837-43. https://doi.org/10.1164/ajrccm.162.3.9905050 ; PMid:10988092.

Article History: Submission Date : 06-12-2016; Revised Date : 07-03-2017; Acceptance Date : 07-04-2017.

Cite this article: Alavudeen SS, Vigneshwaran E, Asiri SAA, Alahmari MHA, Mohammed MA, Algahtani T, Khan NA. Distribution of Multi-Resistant Bacterial Isolates from Clinical Specimens in a Hospital Environment of Kingdom of Saudi Arabia. J Young Pharm. 2017;9(3):347-51. 